\title{
DIVERSIFIKASI PRODUK OLAHAN JAGUNG MANIS SEBAGAI UPAYA PENINGKATAN NILAI TAMBAH BAGI PETANI JAGUNG DI DAERAH WISATA PASIR PANJANG-SINGKAWANG
}

\author{
Maherawati \\ Fakultas Pertanian, Universitas Tanjungpura \\ email : mahera_wati@yahoo.com \\ Sarbino \\ Fakultas Pertanian Universitas Tanjungpura \\ email : sarbinosarbino@yahoo.com
}

\begin{abstract}
ABSTRAK
Pasir Panjang Beach Singkawang is a famous tourist area in West Kalimantan and is one of the corn crops center in Singkawang city. Sweet corn bought as souvenir in the form of fresh vegetables or processed simply into roasted/boiled corn. Corn has not been utilized optimally for various types of food products. To increase the added value of sweet corn for farmers carried out by diversifying corn processing into ice cream, yogurt, and pudding. This activity partner is 35 people member of PKK Group RT 02/06 Kelurahan Sedau, Kecamatan South Singkawang, Singkawang City and Lirang I Farmer Group of Singkawang City. Introduction of technology was done by giving corn processing lectures and the practice of making ice cream, yogurt, and corn pudding. This community service activities can increase the partner's knowledge on corn processing diversification and give the value added of corn. This activity has potensially increased the economic value of corn that will affect the welfare of the community.
\end{abstract}

Key words: processing diversification, sweet corn, Singkawang

\section{PENDAHULUAN}

Kota Singkawang merupakan salah satu bentuk pemerintahan kota di Kalimantan Barat. Terletak di antara Kabupaten Sambas dan Kabupaten Bengkayang, dengan luas wilayah 504 $\mathrm{km}^{2}$. Kota Singkawang terletak pada $0^{\circ} 44^{\prime} 55,85^{\prime \prime}$ - 01 01'21,51" Lintang Utara dan $108^{\circ} 51^{\prime} 47,6^{\prime \prime}-109^{\circ} 10^{\prime} 19^{\prime \prime}$ Bujur Timur. Kota Singkawang berbatasan dengan Kabupaten Sambas di bagian Utara, Kabupaten Bengkayang di bagian Selatan dan Timur, serta Laut Natuna di bagian Barat. Kota Singkawang terdiri dari lima kecamatan yaitu Singkawang Utara, Singkawang Timur, Singkawang Selatan, Singkawang Barat, dan Singkawang Tengah. Sektor pertanian masih menjadi tulang punggung perekonomian di Kota Singkawang, baik dari sisi penghasil nilai 
tambah, maupun sebagai sumber penghasilan atau penyedia lapangan kerja/usaha. Produk unggulan kota Singkawang untuk tanaman palawija adalah jagung, ubi kayu dan ubi jalar. Luas panen jagung 205 ha dengan produksi total 1.016 ton (BPS, 2015).

Pantai Pasir Panjang merupakan daerah wisata yang terkenal di Kalimantan Barat sekaligus sebagai salah satu sentra pertanaman jagung di Kota Singkawang. Oleh karena itu menjadi tempat pemasaran aneka produk kerajinan, kuliner, barang dan jasa dari masyarakat setempat. Salah satu komoditas hasil kelompok tani yang dapat dijual di lokasi tersebut berupa jagung manis. Jagung manis dibeli oleh konsumen sebagai oleh-oleh dalam bentuk sayur segar atau diolah sederhana seperti jagung bakar. Jagung belum dimanfaatkan secara optimal untuk berbagai jenis olahan pangan. Hal ini menjadi masalah bagi petani saat panen raya jagung, karena produksi jagung yang melimpah sehingga harga jual menjadi rendah. Salah satu cara meningkatkan nilai tambah produk jagung adalah dengan mengolahnya menjadi berbagai macam produk olahan jagung yang tahan lebih lama. Produk olahan jagung dapat diunggulkan karena jagung sebagai bahan baku mengandung karbohidrat yang cukup tinggi. Selain itu, jagung juga mengandung protein, lemak, dan serat.

Es krim, yogurt, dan puding jagung merupakan jenis-jenis olahan jagung yang unik dan disukai oleh masyarakat. Es krim dan yoghurt merupakan makanan yang digemari oleh anak muda dan biasanya terbuat bahan dasar susu sapi. Pembuatan es krim dan yoghurt dari jagung dapat menekan harga produksi sehingga harga jual produk dapat disesuaikan dengan kemampuan masyarakat setempat. Es krim dan yoghurt jagung menggunakan bahan dasar susu jagung yang merupakan ekstrak dari jagung manis.

Komposisi jagung manis per 100 gram bahan mengandung 22,8 gram karbohidrat, 3,5 gram protein, serta lemak sebesar 1,0 gram. Asam folat yang terdapat dalam jagung sebesar $129 \mathrm{mcg}$ sangat baik untuk kesehatan ibu hamil dan bayi. Selain itu kandungan zat gizi jagung seperti besi $0,7 \mathrm{mg}$, vitamin A $400 \mathrm{SI}$, dan vitamin B 0,15 mg berperan dalam mencegah anemia pada ibu hamil (Suarni, 2011). Jagung selain mengandung senyawa yang berguna bagi tubuh, juga mengandung senyawa anti nutrisi berupa asam fitat yang dapat menghambat penyerapan mineral dalam tubuh. Oleh karena itu perlu dilakukan cara yang dapat menurunkan atau menghilangkan kandungan asam fitat pada jagung yaitu dengan metode fermentasi (Steinkraus, 2002). Jagung manis memiliki potensi untuk dijadikan bahan pembuatan yoghurt. Karbohidrat dalam biji jagung mengandung gula pereduksi (glukosa dan fruktosa) sukrosa, dan pati. Kadar 
Website : http:// jurnal.untan.ac.id/ index.php/JPLP2KM ISSN : 2620 - 4665 (print)

ISSN : 2620 - 4673 (online)

gula pada endosperm jagung manis adalah sebesar 5-6\% dan kadar pati $10-11 \%$. Sedangkan pada jagung biasa hanya 2 - 3\% atau setengah dari kadar gula jagung manis. Gula yang banyak disimpan dalam biji jagung manis adalah sukrosa sebesar 11\%. Maka dengan kandungan gula tersebut, jagung manis dapat menjadi sumber energi bagi bakteri yang melakukan proses fermentasi (Chairunnisa, 2009).

Pembuatan berbagai jenis produk olahan jagung manis akan menambah nilai ekonomis dan nilai gizi jagung sehingga akan bermanfaatkan bagi peningkatan kesejahteraan masyarakat setempat.

\section{METODE}

Materi diberikan kepada masyarakat melalui metoda ceramah dan praktek. Untuk mengukur pengetahuan dan keberhasilan masyarakat, dilakukan pre test dan post test. Materi yang disampaikan berupa cara pembuatan produk olahan dari jagung manis berupa pembuatan es krim jagung, yoghurt jagung, dan pudding jagung.

\subsection{PEMBUATAN ES KRIM JAGUNG}

Bahan yang dibutuhkan adalah jagung manis ( 5 tongkol), susu cair (1 liter), telur ( 5 butir), gula pasir (250 g), susu skim (50 g), whipe cream (150 g), bahan pengemulsi/SP (2 sdt), CMC $(0,75 \mathrm{~g})$, air (300 $\mathrm{mL})$, garam secukupnya. Cara pembuatan es krim jagung dimulai dengan mencampurkan susu cair dan tongkol jagung ke dalam panci, kemudian dipanaskan hingga mendidih. Setelah itu tongkol jagung dipisahkan dari larutan susu. Selanjutnya dimasukkan susu dengan gula sambil diaduk. Kemudian ditambah CMC, SP, susu skim, air dan garam sambil diaduk hingga homogen. Pisahkan kuning telur dengan putihnya, kemudian kocok kuning telur hingga mengembang. Adonan telur dimasukkan sedikit demi sedikit dalam adonan susu, kemudian dicampurkan ke dalam panci sambil diaduk. Setelah mendidih dan homogen, adonan didinginkan kemudian dimixer hingga mengembang. Selanjutnya adonan didiamkan semalam didalam freezer hingga membeku. 


\subsection{PEMBUATAN YOGHURT JAGUNG}

Bahan pembuatan yoghurt jagung terdiri dari dua bahan. Bahan I adalah susu jagung $(1,5$ liter), susu skim (75 g), CMC (2 g), gula pasir (50 g), dan gelatin (2 g). Bahan II terdiri dari kuning telur (1,125 g), gula pasir (100 g), dan minyak (180 ml). Bahan I dicampur hingga homogen, kemudian dipanaskan hingga suhu $40^{\circ} \mathrm{C}$. Pada wadah lain campurkan bahan adonan II dan dikocok hingga mengembang. Kemudian campurkan adonan II ke dalam adonan I dan dipanaskan hingga homogen. Campuran tersebut dipasteurisasi pada suhu $68^{\circ} \mathrm{C}$ selama 30 menit. Selanjutnya adonan dihomogenisasi pada suhu $60^{\circ} \mathrm{C}$ selama 5 menit dengan menggunakan mixer (diaduk terus), kemudian adonan dimasukkan ke dalam kulkas dengan suhu $4^{\circ} \mathrm{C}$ selama 24 jam. Setelah 24 jam adonan diletakkan pada suhu ruang,dan dimasukkan starter (2\%), dan diinkubasi pada suhu ruang selama 24 jam.

\subsection{PEMBUATAN PUDDING JAGUNG}

Pembuatan pudding jagung dilakukan untuk memanfaatkan ampas jagung hasil pembuatan susu jagung pada pembuatan es krim dan yoghurt. Ampas jagung masih mengandung serat dan nutrisi yang bermanfaat bagi tubuh. Bahan-bahan yang diperlukan adalah ampas jagung manis (500 g), agar-agar (2 bks), gula (250 g), susu skim (50 g), air (1000 ml). Cara pembuatan pudding jagung adalah dengan mencampur air dan agar-agar ke dalam panic, kemudian dipansakan hingga mendidih, setelah itu dimasukkan susu skim dan diaduk hingga homogen. Selanjutnya ditambahkan ampas jagung dan gula sambil diaduk-aduk. Setelah mendidih, kompor dimatikan dan pudding siap dicetak. 


\subsection{EVALUASI KEGIATAN}

Di bagian awal dan akhir kegiatan dilakukan evaluasi kegiatan berupa pengisian kuisioner bagi peserta yang bertujuan untuk mengetahui penguasaan terhadap materi yang diberikan selama pelatihan. Hasil kuisioner dibandingkan sebelum dan sesudah pemberian materi baik ceramah maupun praktek.

\section{HASIL DAN PEMBAHASAN}

Kegiatan pengabdian masyarakat dilakukan mengikuti road map seperti pada Gambar 1. Metode penyelesaian masalah berupa pelatihan kepada mitra kegiatan yang terdiri dari ibu-ibu anggota Kelompok PKK RT 02/06 Kel. Sedau, Kec. Singkawang Selatan, Kota singkawang dan Kelompok Tani Lirang I, Kota singkawang. Jumlah peserta pelatihan sebanyak 35 orang. Pre test dan post test yang dilakukan bertujuan untuk mengetahui dampak pelaksanaan kegiatan terhadap peserta.

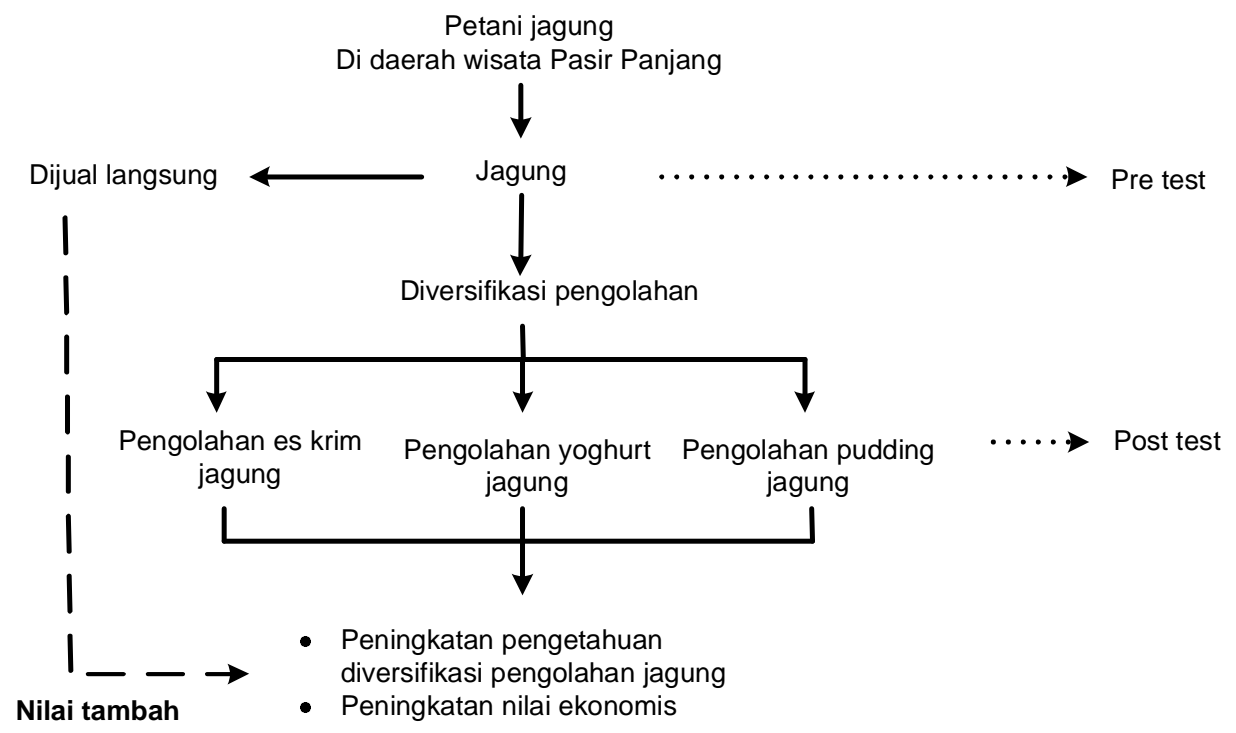

Gambar 1. Road map kegiatan pengabdian kepada masyarakat

Hasil kegiatan pada Tabel 1 menunjukkan bahwa mitra telah banyak memanfaatkan jagung sebagai bahan untuk membuat berbagai produk olahan. Namun mitra belum tahu dan belum pernah mengolah jagung menjadi produk olahan seperti es krim dan yogurt. Hal ini karena masyarakat belum pernah mendapatkan pengetahuan tentang proses 
pembuatan es krim dan yoghurt, sehingga proses pembuatannya dirasa rumit, harga bahan baku mahal ataupun peralatan khusus yang mahal/tidak tersedia.

Tabel 1. Pengetahuan mitra mengenai produk olahan jagung sebelum dan sesudah pelatihan

\begin{tabular}{clcc}
\hline \multirow{2}{*}{ No. } & Produk olahan jagung & \multicolumn{2}{c}{ Pengetahuan mengenai produk } \\
\cline { 3 - 4 } & & Pre test & Post test \\
\hline 1 & Jagung rebus & 100 & 100 \\
2 & Sayur segar & 100 & 100 \\
3 & Jagung bakar & 100 & 100 \\
4 & Sayur Asem & 100 & 100 \\
5 & Bakwan & 100 & 100 \\
6 & Pepes jagung & 100 & 100 \\
7 & Susu jagung & 0 & 100 \\
8 & Yoghurt & 0 & 100 \\
9 & Es krim & 0 & 100 \\
10 & Puding & 12 & 100 \\
\hline
\end{tabular}

Pada umumnya masyarakat mengenal jagung manis sebagian besar dijual dalam bentuk sayur segar dan produk olahan lain berupa bahan sayur asam, bakwan/bala-bala, jagung bakar/rebus dan pepes jagung. Setelah dilakukan introduksi teknologi dengan pemberian ceramah tentang cara pembuatan es krim dan yoghurt jagung, timbul keinginan mitra untuk mencoba. Pada saat dilakukan praktek pembuatan es krim dan yogurt mitra mampu mengerjakan semua langkah dengan baik. Gambar 2 menggambarkan suasana praktek pembuatan olahan jagung manis dalam kegiatan pengabdian masyarakat.
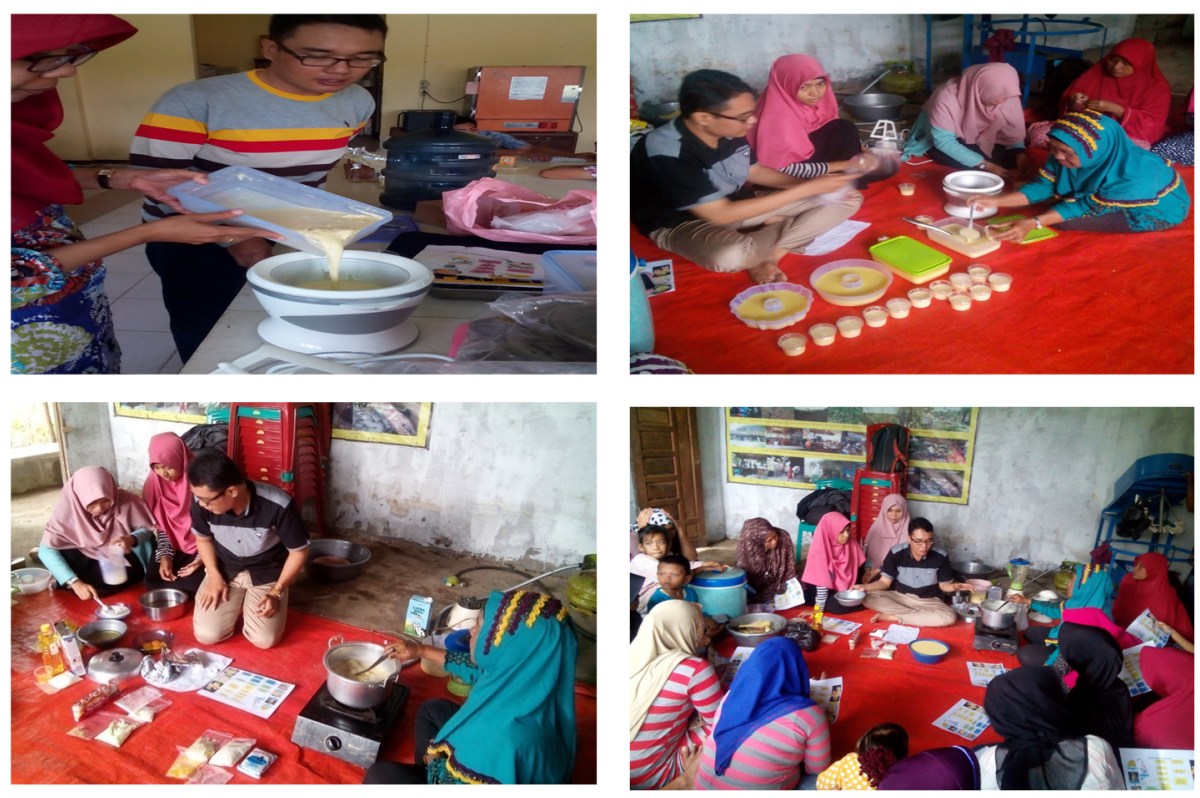

Gambar 2. Suasana praktek pembuatan olahan jagung manis 
Mitra dapat melakukan pengolahan es krim dan yoghurt jagung dengan baik, sedangkan pengolahan pudding sudah biasa dilakukan sehari-hari. Namun hal yang menarik perhatian mitra adalah penggunakan bahan berupa ampas jagung yang selama ini mungkin hanya terbuang begitu saja. Mitra juga sudah mengenal berbagai bahan yang digunakan untuk pembuatan es krim dan yoghurt seperti SP, CMC dan lain-lain karena merupakan bahan tambahan pembuatan berbagai kue yang biasa dibuat oleh masyarakat. Bahan lain yang belum diketahui adalah susu skim dan starter untuk pembuatan yoghurt.

Pembuatan yoghurt membutuhkan bakteri yang berperan dalam fermentasi yaitu Streptococcus thermophilus dan Lactobacillus bulgaricus (Chairunnisa, 2009). Bakteri Lactobacillus bulgaricus berperan pada pembentukan aroma yoghurt. Sedangkan Streptococcus thermophilus berperan pada pembentukan citarasa yoghurt (Surajudin dkk, 2005). Yoghurt memiliki rasa yang khas karena adanya proses fermentasi oleh bakteri, selain itu proses fermentasi menghasilkan produk yang mudah dicerna dan dimanfaatkan tubuh. Dalam kegiatan ini, pembuatan yoghurt jagung menggunakan starter dari minuman susu fermentasi yang sudah banyak tersedia di masyarakat, yaitu "Yakult". Hal ini dilakukan karena mitra belum siap untuk melakukan penyimpanan dan peremajaan kultur bakteri. Selain itu, penggunaan kultur dalam proses pembuatan yoghurt masih sulit dilakukan. Dengan penggunaan starter yang mudah diperoleh diharapkan mitra dalam melakukan pembuatan yoghurt secara mandiri sehingga terampil dan menghasilkan yoghurt berkualitas. Jika mitra sudah menguasai teknik pembuatan yoghurt dengan baik maka pengenalan teknologi peremajaan kultur dapat dilakukan.

Diversifikasi pengolahan jagung manis menjadi es krim, yoghurt, dan pudding jagung menghasilkan nilai tambah ekonomi bagi mitra seperti ditampilkan pada Tabel 2. 
Tabel 2. Analisis ekonomi pembuatan produk olahan berbahan baku jagung manis per satu batch (proses pengolahan per porsi)

\begin{tabular}{llcccc}
\hline No & Produk Olahan & $\begin{array}{c}\text { Harga bahan } \\
\text { Baku }\end{array}$ & $\begin{array}{c}\text { Jumlah } \\
\text { Produk }\end{array}$ & $\begin{array}{c}\text { Harga } \\
\text { Satuan }\end{array}$ & Total Hasil \\
\hline 1 & Yogurt & 35.000 & 50 cup & 1.500 & 75.000 \\
2 & Es krim & 55.000 & 31 cup & 2.500 & 77.500 \\
3 & Puding & 10.000 & 15 potong & 1.000 & 15.000 \\
\hline & Total biaya & 100.000 & & & 167.500 \\
\hline
\end{tabular}

Hasil analisis ekomomi pada Tabel 2 menunjukkan bahwa diversifikasi pengolahan jagung manis menjadi es krim, yoghurt, dan pudding menghasilkan nilai 67,5\% dari harga bahan baku. Hasil ini belum memperhitungkan biaya tenaga kerja dan penggunaan alat, karena pengolahan masih dilakukan secara mandiri. Tingkat keuntungan akan lebih besar apabila produksi dilakukan dalam jumlah lebih banyak. Beberapa pertimbangan memproduksi dalam jumlah besar antara lain produk olahan es krim dan yogurt dapat bertahan beberapa hari, sehingga apt menekan resiko kerugian. Hasil pengamatan kegiatan juga menunjukkan bahwa anak- anak menyukai produk olahan tersebut. Dengan demikian sangat dimungkinkan untuk membuat beberapa batch dalam sekali proses produksi.

Dari kegiatan yang telah dilaksanakan, masih diperlukan adanya kegiatan lanjutan berupa pengembangan pemasaran produk dan pelatihan manajemen keuangan industri rumah tangga sehingga produk yang sudah dihasilkan dapat dikembangkan dan menjadi salah satu sumber penghasilan dari mitra.

\section{SIMPULAN}

Berdasarkan hasil pelaksanaan kegiatan pengabdian kepada masyarakat dengan topik Diversifikasi Produk Olahan Jagung Manis sebagai Upaya Peningkatan Nilai Tambah bagi Petani Jagung di Daerah Wisata Pasir Panjang Singkawang, dapat disimpulkan sebagai berikut:

1. Jagung manis potensial dijadikan produk olahan es krim, yoghurt, dan pudding

2. Mitra mampu melakukan pengolahan jagung menjadi es krim, yoghurt, dan pudding setelah mengikuti pelatihan

3. Diversifikasi pengolahan jagung meningkatkan nilai tambah jagung 
Website : http://jurnal.untan.ac.id/index.php/JPLP2KM ISSN : 2620 - 4665 (print)

ISSN : 2620 - 4673 (online)

\section{DAFTAR PUSTAKA}

BPS, 2015. Singkawang dalam angka 2015. Badan Pusat Statistik, Kota Singkawang.

Suarni, Y. M., 2011. Jagung sebagai Sumber Pangan Fungsional. Iptek Tanaman Pangan 6 (1): $42-56$.

Steinkraus, K.H., 2002. Fermentation in World Food Processing. Comprehensive Reviews in Food Science and Food Safety 1: 23-32.

Chairunnisa, H., 2009. Penambahan Susu Bubuk Full Cream pada Pembuatan Produk Minuman Fermentasi dari Bahan Baku Esktrak Jagung Manis. Jurnal Teknologi Industri Pangan 20 (2): $96-101$.

Surajudin, Kusuma, F. R., Purnomo, D., (2005). Yoghurt Susu Fermentasi Yang Menyehatkan. PT Agromedia Pustaka, Jakarta. 